\title{
WATER SECURITY: IS SOUTH AFRICA OPTIMALLY PURSUING ITS OPTIONS?
}

\author{
JEREMIAH MUTAMBA \\ Trans-Caledon Tunnel Authority, Centurion, South Africa
}

\begin{abstract}
Water is a crucial input to domestic, agricultural and several production activities; it is the source of life and prosperity to many. There is a symbiotic relationship between water and society and, in particular, water influences agriculture, industry, transport, energy, and health. South Africa is a water-scarce country with a considerable projected risk of imbalance between resource requirements and availability. As such, the country needs to manage its limited water resources carefully and prudently to ensure sustainable water security going forward. While the country is working hard to address the challenge, evidence on the round indicates the approach is far from optima - particularly shown by the prevalence of ageing infrastructure due to poor maintenance, high non-revenue water (41\%), widespread river pollution from anthropogenic activities, and limited pursuit of alternative water sources. To improve the country's future water security, a more open embrace of non-conventional water sources and improved efficiencies on the traditional approaches is recommended.
\end{abstract}

Keywords: conventional water sources, water management, water scarcity, water security, South Africa.

\section{INTRODUCTION}

Water is a critical input to domestic, agricultural and several production activities; it is a source of life and catalysis for prosperity to many. Notably, there is a symbiotic relationship between water and society, with water influencing agriculture, industry, transport, energy, and health [1], [2]. Given its pivotal and influential role, it is essential that countries carefully and sustainably manage their water resources. This is particularly essential in areas where water is scarce, as is the case in South Africa. Notably, it is well documented that the country is water scarce and experiences frequent drought spells. Paradoxically, some posit that South Africa does not have a water crisis [3]. Notwithstanding these varying views, South Africa needs to manage its limited water resources carefully and prudently to ensure sustainable water security going forward. One critical question the country faces is whether it is keeping pace with developments and measures to safeguard the country's water security. It is important to note that the security of a country's water resources is found in its infrastructure, institutions and regulatory frameworks that guide the management of water delivery.

This paper looks at critical factors influencing water security in South Africa and interrogates the sustainability of the country's water management approaches. This paper also reviews South Africa's openness to non-conventional water supply sources in light of the level of water scarcity risk. Finally, the paper concludes with recommendations to improve country's long-term water sustainability and resilience.

\section{METHODOLOGY}

This paper is in an exploratory article that reviews current water management approaches in South Africa. The study uses secondary research, particularly making use of extant literature, observations of current management practices, as well as attendant implications and challenges to draw conclusions of whether South Africa is optimally utilising its water resources to ensure water security. The study is designed to help water professionals, 
practitioners, and water resource planners, in South Africa and beyond, to take a broad and considered view of all the potential options available as well as taking key decisions in time.

\section{GLOBAL VIEW ON WATER SECURITY}

Water security is defined as "the reliable availability of an acceptable quantity and quality of water for health, livelihoods, and production coupled with an acceptable level of water-related risk" [1]. Water insecurity is a global phenomenon. Globally, there are over 760 million people with no access to safe drinking water [4]. Over the years this figure is likely to have gone up, given the economic challenges experienced in many places. However, in many cases, the primary problem is not physical scarcity, whereupon demand exceeds supply, but rather socio-economic water scarcity, that is, water scarcity caused by a lack of investment in appropriate water infrastructure or insufficient human capacity to satisfy the demand of water in areas where the population cannot afford to use an adequate water source. A number of factors influence socio-economic water scarcity, including insufficient political will, inadequate investment in water infrastructure projects, lack of skills to manage projects and exclusion of certain groups because of their inability to pay, political affiliation, disability, race or social status. For a country to have a sound water security system, it needs to be able to overcome these impediments.

From the foregoing, it can be said that water availability and access are becoming a critical global risk. It is also clear that a change of approach is needed to better manage water insecurity in a number of nations and local communities. While in some cases, socio-economic water scarcity may overlay physical scarcity, solving socio-economic water scarcity has potential to address the majority of household water stress challenges. However, comprehensive solutions should tackle both physical and socio-economic water scarcity. To fully grasp South Africa's water security position, the following sections look at its water situation as well as highlighting management approaches and challenges experienced.

\section{SOUTH AFRICA'S WATER RESOURCES SITUATION}

South Africa is one of the water-stressed countries in the world; ranked as the 30th driest country globally [5]. The country is predominantly reliant on surface water which accounts for $77 \%$ of water supplies, with the remaining portion supplied from groundwater (9\%) and return flows (15\%) [6]. Notably, a significant portion of the country's surface water resources is imported from neighbouring Lesotho, supporting the country's economic nerve-centre of Gauteng, and most surface water sources have been allocated.

Agriculture is the dominant water user, utilising about $67 \%$ of the country's water, followed by urban use (18\%), mining $(5 \%)$, rural $(3 \%)$ and the remainder distributed among afforestation, power generation and international obligations. The country's reliable surface water yield to be about $14.2 \times 10^{9} \mathrm{~m}^{3} / \mathrm{yr}$ [7]. Further, there is an estimated additional $3.5 \times 10^{9} \mathrm{~m}^{3} / \mathrm{yr}$ of utilisable groundwater available [8]. By 2015, South Africa's water demand was estimated to have reached $15 \times 10^{9} \mathrm{~m}^{3} / \mathrm{yr}$ [9]; with the demand projected to rise to $17 \times 10^{9} \mathrm{~m}^{3} / \mathrm{yr}$ by 2025 .

Considering the above statistics, it can be considered that South Africa currently has enough water to meet its demand, or almost, in balance. It is, however, estimated that demand will outstrip supply by 2025 [7]. Some recent research suggests that water demand would have exceeded available yield by as early as 2017 [9]. Whichever statistics is considered, the message is clear to water professionals; South Africa has limited water resources to cater for its growing demand and, as such, needs to manage its water resources very wisely and optimally. Achieving this requires overcoming several challenges as outlined in the subsequent sections. 


\subsection{Water management in South Africa}

A number of challenges threaten South Africa's long-term water supplies and security. Notable challenges include: that the country is naturally water stressed (physical water scarcity), with most of the river basins and water management areas being in deficit; water requirements continue growing, driven by a growing population, improving livelihoods as well as industrial and agricultural development; aging infrastructure with concomitant high water losses; and continued deterioration of the quality of water in rivers due to anthropogenic-related pollution. Due to the growing demand, the water availability per capita is steadily decreasing.

Further, the country is susceptible and vulnerable to the ravaging effects of climate change, particularly the effects of long-term droughts. For example, over the past 3 years, several parts of the country experienced severe drought episodes, including the devastating drought incidents of 2017 that affected the Eastern Cape, Northern Cape and the Western Cape. These drought episodes were so severe that the City of Cape Town was projected to be running out of water by June of 2018 - an event famously dubbed Day Zero.

While acknowledging some of the advanced water systems that South Africa has [10], amongst which include complex inter-basin transfer schemes and the world-renowned transboundary water transfer from Lesotho, the country's water management needs to improve to ensure it meets present and future strategic needs. More importantly, the systems require improving to ensure resilience. For example, the vulnerability or lack of resilience of the system was exposed through the Western Cape drought, whereupon City of Cape Town struggled to effectively manage the ramifications of the drought. Several areas require improvement including water allocation and water use efficiency across the board; water quality management; preservation of the health of several endangered river systems; infrastructure development and management; and incorporation of climate change principles in both the planning and management of water resources. These issues are further discussed in the next sections.

\subsubsection{Improving water use efficiency}

In terms of water use, three indicators point to non-optimal water management in South Africa. First, records show that South Africa's non-revenue water has increased to 41\% [11], up from $37 \%$ a few years back. While comparable to several other developing countries, which average between $40 \%$ and $50 \%$ [12], this level of unaccounted for water is quite high for any country, let alone for a water-stressed country such as South Africa.

Second, studies have shown that South Africa is over-exploiting its freshwater resources. Several authors indicate that as early as 2015 , the country was over-abstracting its water resources, with annual demand estimated to be 15.6 billion $\mathrm{m} 3$ against a supply $14.6 \mathrm{bn} \mathrm{m} 3$ [13]-[15]. Recent research shows that more than $60 \%$ of South Africa's rivers are being over-exploited [15]. Such practices are unsustainable and, therefore, not recommended and deserve reviewing for improvement.

Third, South Africa's average per capita water consumption of $235 \mathrm{l} / \mathrm{d}$ is considerably too high for a water scarce country, particularly when compared with other water scarce countries around the world.

In particular, this is way above the global average of $185 \mathrm{l} / \mathrm{c} / \mathrm{d}$. Such levels of water consumption, coupled with the high-water losses experienced in the country's water supply networks, further exacerbate South Africa's risk. For a water stressed country, reduced per capita consumption supported by conservation practices will go a long way curtail water supply risk. 


\subsubsection{Water quality and river health management}

The prognosis for South Africa's river health is also not encouraging. Notably, the country's water sources are increasingly being polluted, rendering several water sources unfit for use or making treatment more difficult and costly. Prominent sources of pollution include large volumes of sub-treated wastewater discharged from dysfunctional sewage treatment works, industrial effluents discharged into rivers, mining waste as well as agricultural chemicals runoff into receiving streams. For example, in Gauteng, South Africa's economic hub, 74\% of wastewater treatment works fail to comply with a least two key effluent discharge parameters [2]. Similarly, wastewater works in Limpopo Province seldom treat effluent to acceptable standards [16].

This poor performance of wastewater works observed across the country point to increased threat to South Africa's water quality and, concomitantly, the country's water security. Pollution of water sources reduces resource availability. The Department of Water Affairs' own reports, the Green Drop Reports, reveal that several wastewater treatment plants across the country discharge into rivers effluent that fail to meet regulatory requirements [17]. The reports show that in each year of assessment, between 2009 and 2013, only 50\% of the wastewater treatment plants were compliant - quite a dismal performance. These challenges are influenced by inadequate investment in wastewater treatment infrastructure, shortage of skilled manpower in the sector, poor planning as well as entrenched corruption [18].

Pollution is considered more insidious and much more difficult and costly to remediate [3]. In South Africa, water pollution is projected to reach catastrophic levels in the near future [2]. This is corroborated by a number of scholars who show, through long-term data analysis, show that the quality of most South African rivers and dams has significantly deteriorated over the past 20 years [9], [19]. As remediation of polluted sources is difficult and costly, water contamination therefore poses a huge threat to the country's water security. In addition, water contamination increases water treatment costs. Expanding populations, growing economies and climate change notably continue exerting pressure on quality of water in South Africa. Decrease in water quality results in reduced available water. It also leads to increased treatment costs for both domestic and industrial water. These developments have negative knock-on effects, including reduced crop yields, compromised food security [18], and general societal health.

\subsubsection{Climate change effects}

Climate change impacts the hydrological cycle, altering the quantity and timing of the rains and, subsequently, river flows, coping capacities of water infrastructure and management systems [20]. Climate change is a real threat to national water security. An IPCC report projects that climate change will impact rainfall patterns as well as river flows and levels globally [21]. In South Africa, it is projected that the impacts of climate change on water could exacerbate existing challenges as well as creating new ones. Research indicates that climate change effects in South Africa are likely to: increase flooding or drought in some parts of the country, increase temperature with concomitant increased evaporation, and bring changes to rainfall run-off across the country. Areas particularly projected to experience reduced rainfall and run-off include: the south-west parts of South Africa, the central-western areas and the extreme north. On the contrary, the KwaZulu Natal area, parts of the southern Mpumalanga and the Eastern Cape are projected to experience higher rainfall and extreme run-off. It is, however, important to underscore that both low and high rainfall events compromise the country's water security. As such, appropriate management measures are required to mitigate the effects and impacts of climate change on the country's water security. 
While South Africa has progressed significantly in climate change research and the development of mitigation measures, it recognises gaps remain that still need addressing. Particular knowledge gaps include research on climate change impacts on municipal infrastructure. This is a critical gap considering the growing urbanization and that more than $40 \%$ of the South African population now resides in urban centres [22]. Misra [23] reinforces the existence of gaps in climate change management, citing impacts on groundwater - a resource which needs prioritisation in South Africa as it is currently underutilised.

\subsubsection{Infrastructure development and management}

The state of a country's infrastructure influences and is closely intertwined with a nation's socio-economic growth. In particular, the state of a region's water infrastructure has a bearing on its effectiveness on resource management and stewardship. While South Africa has satisfactory national water resource infrastructure and water services infrastructure in its major metropolitan cities, it faces significant infrastructure quality challenges in many municipalities, particularly in small centres and in rural nodes. A recent SAICE Infrastructure report [24], attests this understanding. The report rates the country's national water resources infrastructure, bulk regional infrastructure, and major urban infrastructure at $\mathrm{D}, \mathrm{C}^{+}$, and $\mathrm{D}^{-}$, respectively. The rating scale used to classify the infrastructure is shown in Table 1. These ratings are low, underscoring the poor state of the country's water infrastructure.

Table 1: Rating scale for South Africa infrastructure report card. (Source: SAICE [24].)

\begin{tabular}{|c|c|c|c|c|}
\hline $\mathrm{A}$ & B & $\mathrm{C}$ & $\mathrm{D}$ & $\mathrm{E}$ \\
\hline World class & $\begin{array}{l}\text { Fit for the } \\
\text { purpose }\end{array}$ & $\begin{array}{l}\text { Satisfactory for } \\
\text { now }\end{array}$ & $\begin{array}{l}\text { At risk of } \\
\text { failure }\end{array}$ & $\begin{array}{l}\text { Unfit for } \\
\text { purpose }\end{array}$ \\
\hline $\begin{array}{l}\text { Infrastructure } \\
\text { is comparable } \\
\text { to the best } \\
\text { internationally } \\
\text { in every } \\
\text { respect. It is in } \\
\text { excellent } \\
\text { condition } \\
\text { and well } \\
\text { maintained, } \\
\text { with capacity } \\
\text { to endure } \\
\text { pressure from } \\
\text { unusual events. }\end{array}$ & $\begin{array}{l}\text { Infrastructure } \\
\text { is in good } \\
\text { condition and } \\
\text { properly } \\
\text { maintained. } \\
\text { It satisfies } \\
\text { current } \\
\text { demands and } \\
\text { is sufficiently } \\
\text { robust to deal } \\
\text { with minor } \\
\text { incidents. }\end{array}$ & $\begin{array}{l}\text { Infrastructure } \\
\text { condition is } \\
\text { acceptable, } \\
\text { although } \\
\text { stressed at peak } \\
\text { periods. It will } \\
\text { need investment } \\
\text { in the current } \\
\text { medium-term } \\
\text { expenditure } \\
\text { framework } \\
\text { period to avoid } \\
\text { serious } \\
\text { deficiencies. }\end{array}$ & $\begin{array}{l}\text { Infrastructure } \\
\text { is not coping } \\
\text { with demand } \\
\text { and is poorly } \\
\text { maintained. It } \\
\text { is likely that } \\
\text { the public will } \\
\text { be subjected to } \\
\text { severe } \\
\text { inconvenience } \\
\text { and even } \\
\text { danger } \\
\text { without } \\
\text { prompt action. }\end{array}$ & $\begin{array}{l}\text { Infrastructure } \\
\text { has failed or is } \\
\text { on the verge } \\
\text { of failure, } \\
\text { exposing the } \\
\text { public to } \\
\text { health and } \\
\text { safety hazards. } \\
\text { Immediate } \\
\text { action is } \\
\text { required. }\end{array}$ \\
\hline
\end{tabular}

The poor state of water infrastructure has several implications on South Africa's water security. Specifically, poor and ageing infrastructure are jointly propagating inefficiencies through increases in water losses. Old and poorly maintained water systems are resulting in high incidence of leakages and bursting of pipes leading to the recorded high non-revenue water for the country. This is also compounded by cases of illegal connections, particularly in informal settlements. As a result, South Africa's non-revenue water levels rose from $37 \%$ to a high $41 \%$. Overall, these statistics signify continued deterioration of water infrastructure network with concomitant threats to both water supply assurance and national water security. 


\subsubsection{Under-investment in water infrastructure}

In addition to the challenges of poor infrastructure maintenance, South Africa struggles to invest in new infrastructure. There is significant under-investment in both water and sanitation infrastructure sectors. For example, the water resources infrastructure sub-sector requires about R70 billion (US $\$ 1 \sim \mathrm{R} 15$ ) per annum in investment; of this requirement, only R43 billion is available, leaving a shortfall of R27 billion annually. The funding shortfall is also exacerbated by historical backlogs associated with previous apartheid regime. A significant number of people still need to be given access to clean and safe water. Taken over years, such infrastructure investment shortfalls inflict huge impacts on the state of the country's water infrastructure as well as the state of water security. The challenge of under-investment and associated implications are, however, not limited to South Africa [25]. The under-investment is also growing as global economies, including South Africa, struggle. As such, South Africa, as other global nations, need to raise the bar in infrastructure investment to address the challenge, inviting all pertinent parties including the private sector.

\section{DISCUSSION}

From the foregoing, it is clear that South Africa needs to seriously look at ways to improve its national water security going forward. While proposed solutions have been researched locally and internationally, optimal combinations need to be considered for the country's best outcomes. Such solutions should be designed at multiple levels, covering the various sectors for greater effectiveness. Solutions can be grouped into technical or behavioural approaches, and comprehensive solutions normally require a combination of both approaches appropriately packaged for greater impact. Technical approaches include traditional engineering solutions involving resource-augmentation projects such as construction of storage reservoirs, transfer schemes and tapping into alternative water sources such as desalinated water and reclaimed water. On the other hand, behavioural approaches include pecuniary and non-pecuniary approaches designed to reduce demand through improved human behaviour. The following sections look at the options that South Africa can explore, with the options divided into traditional (conventional) approaches and nonconventional approaches. Traditionally, supply-side and technical solutions have been more favoured. This, however, has to change going forward if optimal water management is to be achieved.

\subsection{Conventional water management approaches}

Key among conventional options is the exploration of new groundwater and surface water resources, supported by use of advanced engineering. This approach has worked for long, with greater focus on surface water development. However, in South Arica, 98\% of the affordable and viable surface water resources have been allocated. The WARMS database shows that the country's estimated water use ranges between 15 and 16 billion m3/annum, nearly exceeding reliable yield [6]. With most of the surface water resources almost allocated, there is very little room for cheap and easy to access water resources to tap into. In addition, the country is not endowed with many high-yielding aquifers. Under these circumstances, two options to improve the country's water security obtain and are proposed. These options comprise: (i) optimizing use of the limited surface water resources, and (ii) reviewing current allocations in view of growing demand and future requirements.

For a country with $41 \%$ non-revenue water, considerable room exist to improve, gaining efficiencies in water use per capita through demand management and conservation strategies. Also, the country can optimally develop the remaining few surface water resource sites. However, optimised development of the few remaining surface water sites could attract a 
higher unit price, while water reallocation may be resisted by current water right holders. Such decisions, although not popular among existing water rights holders, are necessary to ensure equitable use as well as sustainable water supply for the future. Demand management and water conservation strategies are, unfortunately, not the favourite options for political decision-makers. Nonetheless, for improved national water security, tough decisions are required, calling for all to contribute to the success.

\subsection{Non-conventional water management approaches}

Severe resource scarcity at all times call for a shift from traditional approaches to new approaches, including historically non-conventional options. It is, however, essential to introduce such approaches carefully, professionally and without exposing people to undue risk. In this regard, under growing water resource limitations, it is time South Africa embraces and, timeously, start incorporating non-conventional options such as sea water desalination and water reclamation options into the water mix. It is recognised that these options have been recommended for South Africa by the water professionals and officials, and that they appear in the country's strategies and future water mix options, particularly in reconciliation strategies for most water management areas. South Africa even has national strategies, as part of the National Water Resources Strategy [26], for desalination and water reuse; evidence of strategic commitment by the country on the two options.

However, what is clearly lacking is the will power to implement projects from this domain, and to make such decisions promptly to enable timely and effective implementation. Current practice shows that only and only when there is a severe water crisis, usually triggered by drought, are non-conventional water options accorded priority. A classical case in point is the prioritisation of both seawater desalination and water reuse in Cape Town when the region is experiencing severe drought episode. Prior to the drought, seawater desalination and water reuse ranked lower in the City's water reconciliation strategies - only to be accorded priority during the drought period when the City experienced severe water shortages. These options should not be considered crisis options, but rather be considered as normal options at all times. At such instances, these projects are hastily considered and implemented usually at a high premium. Such an approach is not cost efficient, resulting in end-users paying exorbitant price for the water. Sadly, because of the hurried nature of the decisions and the associated premiums such hurried decisions attract at heightened risk, these options will always be viewed as second class options when reviewed during normal times. The evident reactionary approaches result in non-optimal and unsustainable solutions to the country's water supply systems.

\section{CONCLUSIONS}

South Africa's long-term water security cannot not be said to be fully guaranteed - the faces a number of challenges and has a lot of work to do to ensure assured water security going into the future. Physical water scarcity provides a backdrop that complicates the efforts towards improved water security as this calls for considerable capital investment to diversify the mix for limited resource. While the country is working hard to address the challenge, its approach is not yet optimal as evidenced by the prevalence of ageing infrastructure, significantly high non-revenue water, growing river pollution from anthropogenic activities as well as the limited pursuit of alternative water sources. In order to improve the country's future water security, a more open embrace of non-conventional water sources as well as improved efficiencies on the traditional approaches are recommended, and senior decision-makers need to take the lead. 


\section{REFERENCES}

[1] Grey, D \& Sadoff, C.W., Water for Growth and Development in Thematic Documents of the IV World Water Forum, Commission Nacional del Agua: Mexico, 2006.

[2] van der Merwe-Botha, M., Water Quality: A Vital Dimension of Water Security, Development Planning Division Working Paper Series No. 14, Development Bank of South Africa: Midrand, 2009.

[3] Muller, M., Schreiner, B., Smith, L. \& van Kloppen, B., Water Security in South Africa, Development Planning Division Working Paper Series No. 12, Development Bank of South Africa: Midrand, 2009.

[4] Water Aid, Water security framework, 2012.

[5] Green Cape, Water. Market Intelligence Report, 2017.

[6] DWA, Strategic overview of the water resources in South Africa, 2013.

[7] National Treasury, Estimates of national expenditure, 2011.

[8] DWA, Groundwater availability. Newsletter \# 5: Groundwater in the national water balance, 2011.

[9] WWF, Water: Facts and futures. Rethinking South Africa's water future, 2016.

[10] Munzhedzi, S. \& Mqguba, S.K., Climate Change and the Water Sector. Climate and Impacts Factsheet Series, Department of Environmental Affairs: Pretoria, n.d.

[11] DWS, National water and sanitation master plan, 2018.

[12] World Bank, The challenge of reducing non-revenue water in developing countries. How private sector can help: A look at performance-based services contracting, 2006.

[13] WRG, Charting our water future. Economic frameworks to inform decision-making 2030, 2009.

[14] Hedden, S. \& Celliers, J., Perched prospects: The emerging water crisis in South Africa. The Water Wheel, November/December, 2014.

[15] Donnenfeld, Z., Crookes, C. \& Hedden, S., A delicate balance. Water scarcity in South Africa. A South Africa Report, 13, 2018.

[16] Ogola, J.S., Chimuka, L. \& Maina, D., Occurrence and fate of trace metals in and around treatment and disposal facilities in Limpopo Province, South Africa (a case of two areas). Proceedings of IASTED International Conference on Environmental Management and Engineering, 2009.

[17] DWA, 2013 Green drop report, Vol. 2, 2013.

[18] Edokpayi, J.N., Odiyo, J.O. \& Durowoju, O.S., The Impact of Wastewater on Surface Water Quality in Developing Countries: A Case Study of South Africa, 2017.

[19] WWF, Scenarios for the future of water in South Africa. 2017.

[20] Zhu, T. \& Ringler, C., Climate change impacts on water availability and use in the Limpopo River Basin. Water, 4, pp. 65-84, 2012.

[21] IPCC, Climate change and water. Intergovernmental Panel on Climate Change, 2008.

[22] Kundzewicz, Z.W. et al., Freshwater resources and their management. Climate Change 2008. Impacts, Adaptation and Vulnerability, eds M.L. Parry, O.F. Canziani, J.P. Palutikof, P.J. van der Linden \& C.E. Hanson, Cambridge University Press: Cambridge, pp. 173-210, 2007.

[23] Misra, A.K., Climate change and challenges of water and food security. International Journal of Sustainable Built Environment, 3, pp. 153-165, 2014.

[24] SAICE, SAICE 2017 infrastructure report card for South Africa, 2017.

[25] Yaari, E., Earle, A., Mpakama, Z., Kruger, A. \& Menouer, L., Water Infrastructure Finance Constraints: Shared Lessons from Africa and Europe, Stockholm Institute Water Institute: Stockholm, 2019.

[26] DWA, National water resources strategy, 2013. 